\begin{tabular}{|c|c|c|c|}
\hline $\begin{array}{l}\text { Case Reports in } \\
\text { Dematoloy }\end{array}$ & $\begin{array}{l}\text { Case Rep Dermatol 2011;3:32-36 } \\
\text { DOI: } 10.1159 / 000324721\end{array}$ & \begin{tabular}{|l} 
Published online: \\
February 18,2011
\end{tabular} & $\begin{array}{l}\text { () } 2011 \text { S. Karger AG, Basel } \\
\text { ISSN } 1662-6567 \\
\text { www.karger.com/cde }\end{array}$ \\
\hline
\end{tabular}

\title{
Giant Hemosiderotic Dermatofibroma: A Case Report and Review of the Literature
}

\author{
Marc Pusztaszeri ${ }^{\mathrm{a}} \quad$ Pierre-Yves Jaquet $^{\mathrm{b}} \quad$ Carole Williamson $^{\mathrm{c}}$ \\ ${ }^{\mathrm{a} D i v i s i o n}$ of Clinical Pathology, Geneva University Hospital, Geneva, ${ }^{\mathrm{b}}$ General \\ Practitioner, Bassins, and 'Pathology and Cytology Laboratory, Unilabs-Cytopath, \\ Geneva, Switzerland
}

\section{Key Words}

Giant dermatofibroma - Hemosiderotic dermatofibroma · Fibrous histiocytoma

\begin{abstract}
Dermatofibroma is a common benign fibrohistiocytic lesion that usually appears as a slow-growing, firm dermal nodule with a predilection for the legs of middle-aged women. They are usually smaller than $2 \mathrm{~cm}$ in diameter. Many histological variants have been described. Generally, the clinical and histological diagnosis is straightforward, but differentiating it from other cutaneous tumors can be difficult in atypical cases and rare variants. Giant dermatofibroma is a rare clinical variant of dermatofibroma and less than 25 cases have been reported. It is characterized essentially by its unusually large size, which often mimics malignant tumors clinically. We first present the case of a giant hemosiderotic dermatofibroma in a 54-year-old patient, who presented with a large ulcerated mass of the left foot which was excised, and then review the literature briefly.
\end{abstract}

\section{Introduction}

Dermatofibroma (DF; fibrous histiocytoma) is a spectrum of benign fibrohistiocytic tumors, which presents with a wide variety of clinical and histopathological features. Most measure between 0.5 and $2 \mathrm{~cm}$, are often found on the limbs and trunk and can be recognized clinically by pinching the suspected nodule between the finger and thumb and observing that it is fixed within the dermis. It is usually asymptomatic, although pruritus and tenderness are not uncommon. Removal of the tumor is not necessary unless diagnostic uncertainty exists or disturbing symptoms are present. Giant DF, in contrast, is a very uncommon variant, larger than $5 \mathrm{~cm}$ and often polypoid, and the clinical diagnosis is obscure. We present a case of a giant DF (hemosiderotic type), in a 54-year-old patient, and review the literature on the condition briefly. 


\begin{tabular}{c|l|l|l}
$\begin{array}{c}\text { Case Reports in } \\
\text { Demmatoloyy }\end{array}$ & $\begin{array}{l}\text { Case Rep Dermatol 2011;3:32-36 } \\
\text { DOI: } 10.1159 / 000324721\end{array}$ & $\begin{array}{l}\text { Published online: } \\
\text { February 18, 2011 }\end{array}$ & $\begin{array}{l}\text { O 2011 S. Karger AG, Basel } \\
\text { ISSN 1662-6567 } \\
\text { www.karger.com/cde }\end{array}$ \\
\hline
\end{tabular}

\section{Case Report}

A 54-year-old patient, known to have type 2 diabetes, presented with a large ulcerated mass of the left foot. The lesion had been present for about 20 years and had initially been pea-sized. Over the last one a half years before case presentation, its size had increased up to $5 \mathrm{~cm}$, and it had become painful and ulcerated. A similar 1-cm lesion was also present on the right leg (fig. 1a). Surgical resection of the mass and total skin graft were performed. One and a half years after surgery, the patient is well and has a healthy-looking scar with no signs of recurrence (fig. 1b).

Macroscopic examination showed a large ulcerated cutaneous mass, measuring $5.1 \times 4 \times 1.5 \mathrm{~cm}$ (fig. 2a). It had a pedunculated appearance with a large circular stalk measuring $3 \mathrm{~cm}$. On cut section, the mass was solid and heterogeneous with white and brown areas (fig. 2b). No necrosis or cysts were seen. Histological examination revealed an ill-defined dermal proliferation of elongated fibrohistiocytic cells. Cellularity was variable with hypocellular and collagenized areas alternating with more cellular areas, sometimes of storiform pattern (fig. $3 \mathrm{a})$. Some occasional moderate nuclear atypia was seen. No mitotic activity or necrosis was found. There were some giant multinucleated (Touton-like) cells and numerous tumor cells with brown hemosiderin pigment (positive with Prussian blue stain) (fig. 3b). At the borders of the lesion, collagenous nodules were seen entrapped between tumor cells. There was a grenz zone between the tumor and the overlying epidermis, which was focally ulcerated. The histological diagnosis was giant hemosiderotic DF.

\section{Discussion}

Typical DF are usually smaller than $3 \mathrm{~cm}$. Usually, the clinical and histological diagnosis is simple, but distinguishing it from other cutaneous tumors can be difficult in atypical cases and rare variants. Giant DF is a rare clinical variant of DF which is characterized by its unusually large size. The following characteristics have been accepted for giant DF [1,2]: (a) a size of $\geq 5 \mathrm{~cm}$, (b) pedunculated appearance, (c) benign biological behavior despite its size, and (d) the same histopathological characteristics as conventional DF. If those criteria are applied, only 23 cases of giant DF have been described previously in the literature. They usually present as exophytic lesions, up to half of which are pedunculated. Most frequently, they are located on the legs, especially below the knee and on the foot, followed by location on the back [1-3]. Because of their large size, the correct diagnosis is frequently not reached from clinical examination alone, and a diagnosis of malignancy is often made. The differential diagnosis usually includes malignant lesions such as basal cell or epidermoid carcinoma, dermatofibrosarcoma protuberans or other sarcomas. However, histopathological study confirms the diagnosis by demonstrating the typical characteristics of DF. The varied histological spectrum seen in usual DF can also be seen in giant DF $[4,5]$. Xanthomatous cells are present in up to half of the cases [2].

Giant DF have also been reported with atypical/pleomorphic, lipidized, granular cells [6] and combined histological characteristics [2]. Some alleged cases of giant DF reported in the literature are in fact aneurysmal DFs $[7,8]$. This is another uncommon histologic variant. It is usually larger than typical DF and may show rapid growth, mainly due to the presence of numerous blood-filled cavernous cavities and hemorrhage, often within the background of a hemosiderotic DF. In our case, the macroscopic brown color and numerous hemosiderophages seen microscopically correspond to a hemosiderotic variant.

The histopathological features of several variants may also coexist in the same lesion and may correspond to different stages of the same disease. Some authors consider 


\begin{tabular}{c|l|l|l}
$\begin{array}{c}\text { Case Reports in } \\
\text { Demmatoloyy }\end{array}$ & $\begin{array}{l}\text { Case Rep Dermatol 2011;3:32-36 } \\
\text { DOI: } 10.1159 / 000324721\end{array}$ & $\begin{array}{l}\text { Published online: } \\
\text { February 18, 2011 }\end{array}$ & $\begin{array}{l}\text { O 2011 S. Karger AG, Basel } \\
\text { ISSN 1662-6567 } \\
\text { www.karger.com/cde }\end{array}$ \\
\hline
\end{tabular}

hemosiderotic DF a precursor lesion in the development of aneurysmal DF $[9,10]$. Our case, illustrating a giant hemosiderotic DF, is in agreement with this theory. To our knowledge, only one case of hemosiderotic giant DF has been reported but has not been illustrated previously $[1,2]$. Giant DF can appear de novo or secondary from a preexisting and longstanding smaller lesion $[5,8]$ such as was the case in our patient. The origin (reactive or neoplastic) of DF including its giant variant is still unclear and debated. Some authors think that it is neoplastic because of the persistent nature of the lesion and the fact that the proliferating cells are clonal $[11,12]$. However, clonality can also be seen in reactive and inflammatory conditions, including atopic dermatitis, lichen sclerosis, and psoriasis. Because of its fibrohistiocytic nature, the persistence of the lesion is not proof of its neoplastic nature and may be partly attributed to intrinsic fibrosis which does not usually regress, as it is the case for scars; neither is the fact that some DF can be gigantesque and larger than $5 \mathrm{~cm}$ decisive in that question since large size and rapid growth can be seen in other reactive processes/tumors such as nodular fasciitis. It is likely that DF is a heterogeneous process. The clonal genotype found in DF with histiocytoid or predominant histiocytoid features suggests that histiocytoid cells probably represent the neoplastic component [12]. Conversely, the fibroblastic form of DF may represent a reactive fibroblastic proliferation. Alternatively, it may represent a true neoplasm whose neoplastic cell type has been obscured by a prominent reactive fibroblastic component [12]. No recurrence has been reported after complete surgical excision of giant DF.

In conclusion, we report another rare and interesting variant of giant DF, which is extremely difficult to diagnose clinically but not histologically, with an excellent clinical outcome.
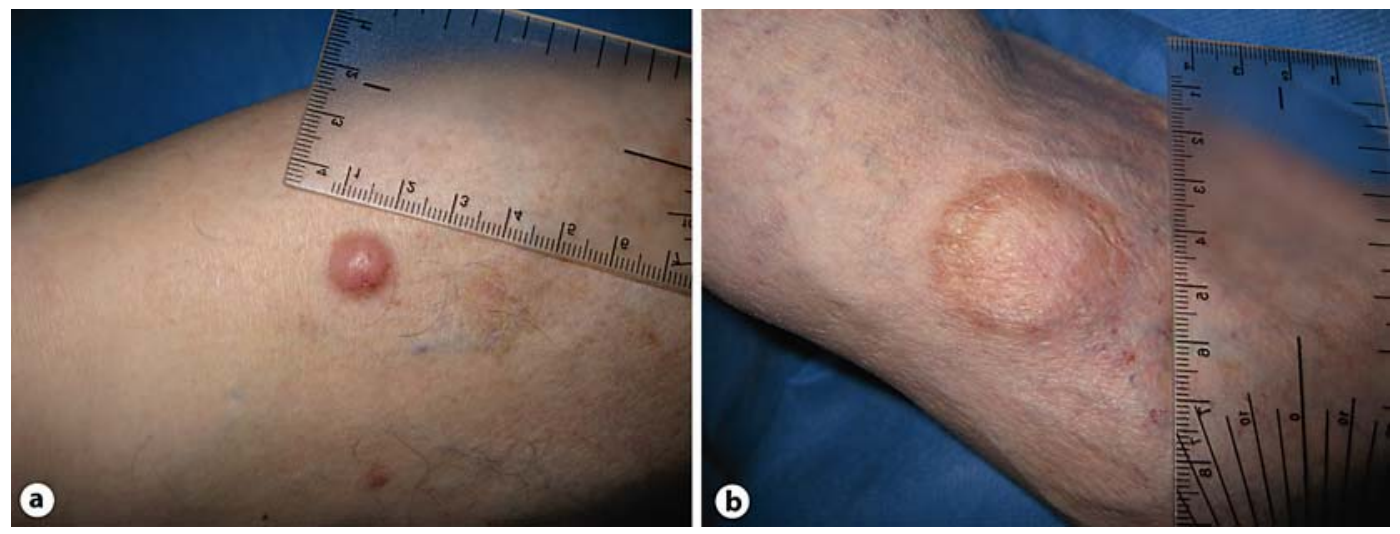

Fig. 1. a Small reddish cutaneous nodule on the right leg, consistent with DF. b Appearance of the scar 1.5 years after surgery. 


\begin{tabular}{c|l|l|l}
$\begin{array}{c}\text { Case Reports in } \\
\text { Dermatology }\end{array}$ & $\begin{array}{l}\text { Case Rep Dermatol 2011;3:32-36 } \\
\text { DOI: } 10.1159 / 000324721\end{array}$ & $\begin{array}{l}\text { Published online: } \\
\text { February 18, 2011 }\end{array}$ & $\begin{array}{l}\text { O 2011 S. Karger AG, Basel } \\
\text { ISSN 1662-6567 } \\
\text { www.karger.com/cde }\end{array}$ \\
\hline
\end{tabular}
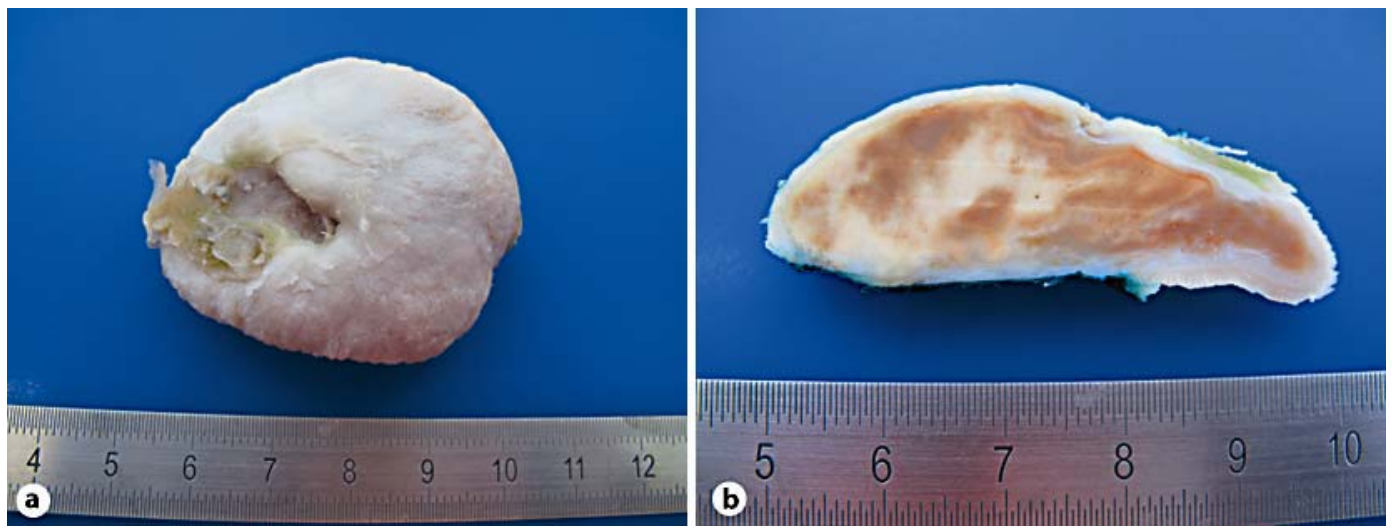

Fig. 2. a Large polypoid and ulcerated cutaneous mass excised from the patient's leg. b On cut section, it is found to be solid with brown and white areas.
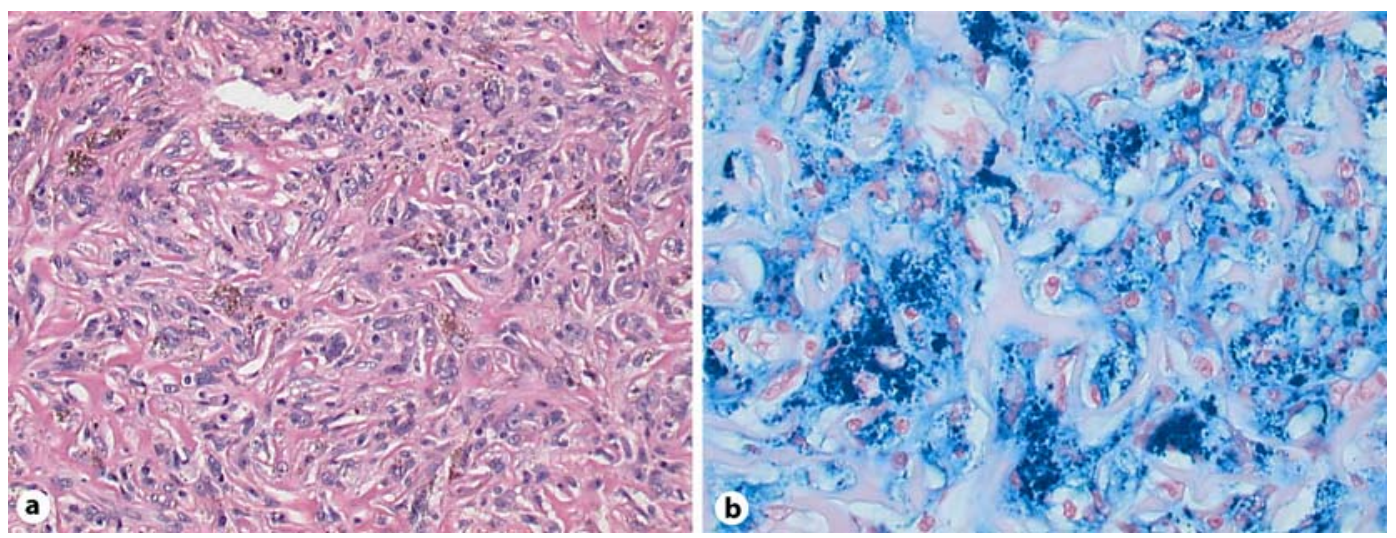

Fig. 3. a Histology shows a proliferation of fibrohistiocytic cells with a focal storiform pattern. Some cells contain brown granular hemosiderin pigment $(\mathrm{HE}, \times 200)$. b The pigment is positive with Prussian blue stain $(\times 400)$.

\section{References}

1 Requena L, Fariña MC, Fuente C, Piqué E, Olivares M, Martín L, Sánchez Yus E: Giant dermatofibroma: a little-known clinical variant of dermatofibroma. J Am Acad Dermatol 1994;30:714-718.

$>2$ Hueso L, Sanmartín O, Alfaro-Rubio A, Serra-Guillén C, Martorell A, Llombart B, Requena C, Nagore E, Botella-Estrada R, Guillén C: Giant dermatofibroma: case report and review of the literature. Actas Dermosifiliogr 2007;98:121-124.

3 Hoshina D, Shibaki A, Aoyagi S, Kimura K, Shimizu H: Giant dermatofibroma: a rare variant of dermatofibroma preferentially developing on the lower limbs. Clin Exp Dermatol 2007;32:132-134.

4 Puig L, Esquius J, Fernández-Figueras MT, Moreno A, de Moragas JM: Atypical polypoid dermatofibroma: report of two cases. J Am Acad Dermatol 1991;24:561-565.

-5 Sato N, Aiba S, Maie O, Tomita Y: Giant xanthomatous dermatofibroma - a case distinguished histologically and immunohistochemically from invasive fibrohistiocytic tumors. Dermatology 1995;190:67-71.

-6 Rhee DY, Lee HW, Chung WK, Chang SE, Lee MW, Choi JH, Moon KC, Koh JK: Giant dermatofibroma with granular cell changes: side-effect of bee-venom acupuncture? Clin Exp Dermatol 2009;34:e18-e20. 
7 Kawakami Y, Oyama N, Nishibu A, Nakamura K, Kaneko F: A case of 'giant' aneurysmal benign fibrous histiocytoma. Clin Exp Dermatol 2006;31:456-457.

8 Lang KJ, Lidder S, Hofer M, Graham C, Taylor A: Rapidly evolving giant dermatofibroma. Case Report Med 2010;2010:620910.

9 Scalvenzi M, Balato A, De Natale F, Francia MG, Mignogna C, De Rosa G: Hemosiderotic dermatofibroma: report of one case. Dermatology 2007;214:82-84.

10 Zaballos P, Llambrich A, Ara M, Olazarán Z, Malvehy J, Puig S: Dermoscopic findings of haemosiderotic and aneurysmal dermatofibroma: report of six patients. Br J Dermatol 2006;154:244-250.

11 Chen TC, Kuo T, Chan HL: Dermatofibroma is a clonal proliferative disease. J Cutan Pathol Jan 2000;27:3639.

12 Hui P, Glusac EJ, Sinard JH, Perkins AS: Clonal analysis of cutaneous fibrous histiocytoma (dermatofibroma). J Cutan Pathol 2002;29:385-389. 